\title{
Sürdürülebilir Üniversitelerin Yönetişim-Strateji Çalışmaları ve İletişimi İçin Karşılaştırma Bazlı Bir Yaklaşım Önerisi
}

\author{
Esra BAYHANTOPÇU* \\ Pınar Gökçin ÖZUYAR**
}

\begin{abstract}
ÖZ
Sürdürülebilirlik kavramının gittikçe önem kazandığı günümüzde, sürdürülebilirlik çalışmaları üniversitelerde de önem kazanmava bașlamıș ve birçok üniversite, sürdürülebilir bir üniversite olma taahhüdünde bulunmak için süreçlerini yeniden organize etmeye başlamıştır. Bu alanda yol gösterici olmak için, üniversiteler için de bu konuda sürdürülebilirlik sıralama sistemleri geliștirilmeye bașlanmıştır. Bu çalışmada sürdürülebilir bir üniversitenin yönetişim, strateji ve iletișim çerçevesinde önceliklendirmesi gereken temel göstergelerinin belirlenmesi amaçlanmıştır. Bu amaca yönelik olarak, THE Impact, UI GreenMetric ve GRI olmak üzere yavgın olarak kullanılan üç küresel sürdürülebilirlik sıralama ve raporlama endeksinin yönetișim ve strateji yönlerine dayalı karşılaştırmalı analiz yapılmıştır. Bu çerçevede; sürdürülebilir bir üniversitenin strateji ve yönetişim çalışmalarının hangi kapsamlarda yapılandırılması gerektiğinin ortaya çıarılması ve bu kapsamda sürdürülebilirlik iletişimi için gerekli olan araçların incelenmesi yapılmıştır. Yapılan karşılaştırmalı analiz, yönetişim ve strateji alanı altındaki dört ana başlı̆̆ kapsamaktadır. Bu bașliklar; ‘Temel Strateji ve Politikalar/Yönetim Yapısı', 'Etik', 'Sosyal Alanlar' (Cinsiyet Eşitliği, Eșitlik ve Çeşitlilik, İnsan Hakları) ve son olarak 'Çevresel Etki Politikaları’ndan oluşmaktadır. Çalışmada ayrıca, ilgili göstergelerin karşılaştırılması ve gelecekteki eylemler ile ilgili daha fazla kavrayışın tartışılması sunulmaktadır.

Anahtar Kelimeler: Sürdürülebilir Üniversite, Sürdürülebilirlik, Yönetişim, Strateji, İletişim, Sürdürülebilirlik İletişimi, Sürdürülebilirlik Endeksleri.
\end{abstract}

\section{A Proposal For Sustainable Universities' Governance-Strategy and Communication Studies by a Comparative-Based Approach}

\begin{abstract}
Sustainability has become a prominent aspect in universities and many universities are using tools to declare their commitment to being a sustainable university. Sustainability ranking systems have started to be developed for universities in order to be a guide in this area. This study aims to determine the basic indicators that a sustainable university should prioritize within the framework of governance, strategy and communication. To achieve this goal, a comparative analysis has done and a proposal is developed based on governance and strategy aspects of three commonly used global methods of ranking and reporting, i.e. THE Impact, UI GreenMetric and GRI. In this context; It is aimed to reveal the scope in which the strategy and governance studies of a sustainable university should be structured that highlight the issue of sustainability, and to examine the tools required for sustainability communication. The comparative analysis yield four main headings of the proposed approach, as; 'Fundamental Strategy and Policies/Management Structure', 'Ethics', 'Social Aspects' (Gender Equality, Equality and Diversity, Human Rights) and finally 'Environmental Impact Policies'. Furthermore, the comparison of relevant indicators and discussion of further insight to future actions is presented.
\end{abstract}

Keywords: Sustainable University, Sustainability, Governance, Strategy, Communication, Sustainability Communication, Sustainability Indexes.

\section{Giriş}

Dünyanın gündemine oturan ve artık tüm kurum ve kuruluşların gerek ekonomik, gerek çevre gerekse toplum bacağında sürdürülebilirlik çalışmalarını kendi çerçevelerinde yürüttüğü günümüzde, üniversitelerin de bu çalışmaların gerisinde kalması beklenemez. Sürdürülebilir Üniversite kavramının temelinde, Dünya Çevre ve Gelişim Komisyonu (World Commission on Environment and Development - WCED) raporunda kısaca 'şimdiki ihtiyacı karşılarken gelecek nesillerin yaşayışını tehlikeye atmamak' olarak tanımlanan sürdürülebilir kalkınma kavramı yer almaktadır (WCED, 1987). Bu tanım herhangi bir kurumun gelişmesi ve kalkınmasında sosyal, ekonomik ve çevresel etkileri tam bir dengede tutmak gereğini içermektedir. Bu da, üniversiteler için de geçerliliği kabul edilmiş triple-bottom-line / üçlü temel teorisini de ortaya koymaktadır (Ragazzi \& Ghidini, 2017, s. 111). Üniversiteler aynı zamanda sürdürülebilirlik konusundaki toplumsal bilinci artırma görevini üstlenmektedirler (Lauder vd., 2015, s. 852). Üniversitelerin

\footnotetext{
* Dr. Öğr. Üyesi, İstinye Üniversitesi, esra.bayhantopcu@istinye.edu.tr

** Dr. Öğr. Üyesi, İstinye Üniversitesi, pinar.ozuyar@istinye.edu.tr

Makalenin Gönderim Tarihi: 05.01.2021 , Makalenin Kabul Tarihi: 25.03.2021
}

doi: 10.52642 /susbed. 929913 
eğitim-öğretim ve araştırma dışındaki bu misyonu da, özellikle son zamanlarda sürdürülebilirlik konusunun artan şekilde akademik yapı içinde ele alınmasına neden olmuştur (Lozano vd., 2015, s. 1).

$\mathrm{Bu}$ noktada üniversitelerin sürdürülebilirlik çalışmalarının ne şekilde olması gerektiği, öncelikli hangi konulara odaklanılması, eğitim-öğretim ve araştırma misyonlarına sahip olan üniversitelerin toplumsal katkıyı nasıl maksimize edeceği noktasının da önem kazanması, bugün üniversitelerin yönetişim şekillerini gözden geçirmelerine sebebiyet vermektedir. Ayrıca bu konuda yapılan strateji iletişimi, çalısmaların yaygınlaşması ve bilinir kılınması açısından önem kazanmıştır. Bununla birlikte üniversitelerin söz konusu çalışmalarına rehber olmak ve aynı zamanda sürdürülebilirlik çalışmalarının itici gücü olarak hizmet eden gereken belgelendirme için üniversite derecelendirme endeksleri sürdürülebilirlik konularını da kapsamaya başlamıştır.

Bahsi geçen sıralama sistemleri belli kriterleri göz önüne alarak küresel ya da ülke bazlı olabilmektedir. Bunun sonucu olarak da gittikçe artan sayıda akademik ve akademi dışı çalışma da konuya olan ilgiyi artırmaktadır (Thakur, 2007, s. 86). Bu noktada sürdürülebilirlik alanı içinde yer alan ekonomik katkı; çevresel uygulamalar; insan hakları, eşitlik, hizmet sorumluluğu ve çalışanlara yönelik uygulamalar da dahil olmak üzere toplumsal kalkınma çalışmaları kapsamında temel yönetişim ve stratejilerin net olması daha da öncelikli hale gelmiştir. Böylece çalışmanın konusu olan ve küresel olarak üniversitelerde uygulanan seçilmiş üç endeksin yönetişim ve strateji açısından karşılaştırılması önem kazanmıştır.

$\mathrm{Bu}$ çalş̧mada sürdürülebilir bir üniversitenin yönetişim strateji ve iletişim çerçevesinde önceliklendirmesi gereken temel göstergelerinin belirlenmesi amaçlanmıştır. Bu amaca yönelik olarak; çalışma kapsamında amaca uygun örneklemden yararlanarak, sürdürülebilirlik alanında en yaygın olarak kullanılan 3 temel endeks belirlenmiştir. Üniversite endekslerinden sürdürülebilirlik konusunu öne çıkaran Times Yüksek Öğrenim Etki Sıralaması (Times Higher Education World University Rankings - THE Impact); çevresel çalş̧maların önemine vurgu yapan IU GreenMetric Dünya Üniversite Endeksi (IU GreenMetric World University Ranking) ve kurum ve kuruluşların genel sürdürülebilirlik çalışmalarını değerlendiren ve dünyada en çok kullanilan standart olan Küresel Raporlama Girişimi (Global Reporting Initiative - GRI) sürdürülebilirlik raporlaması standardı endeksleri örnekleme alınmıștır. Endekslerin tüm göstergeleri incelenerek strateji ve yönetişim alanlarına yönelik göstergeleri çıkarılmış ve belirlenen bu göstergelerin karşılaştırmalı analizi, içerik analizi metodundan da yararlanılarak yapılmışıtır. Bununla birlikte bu kapsamda sürdürülebilirlik iletişimi için gerekli olan araçların örnekleri de ele alınmıştır. Bu çerçevede, sürdürülebilir bir üniversitenin yönetişim strateji ve iletişim çerçevesinde önceliklendirmesi gereken temel göstergelerine dair bir yaklaşım önerisi sunulmuştur.

\section{2. Üniversitelerde Kullanılan Sürdürülebilirlik Endeksleri ve İletişiminin Önemi}

Günümüzde kurumların tüm paydaşlarına yönelik olmak üzere çevre ve topluma ilişkin sorumlulukları giderek daha fazla önem kazanmaktadır. Bunun sonucu olarak, yol gösterici olmak için, üniversiteler için de bu konuda sürdürülebilirlik sıralama sistemleri geliştirilmeye başlanmıştır.

Bir üniversite sürdürülebilirlik sıralama sistemi, sürdürülebilirliği bir yükseköğretim kurumunun sürdürülebilirlik konusundaki performansını (veya beklenen performansını) belirleyecek noktaları netleştirmesini ve bu değerlendirmeyi benzer kurumlarla karşılaştırmasını sağlayan ve sonucunda genel bir değerlendirmeye dönüştüren bir araç olarak tanımlanabilir.

Üniversite sürdürülebilirlik sıralama sistemleri, bu konuda gittikçe artan küresel bir rekabetin ortaya çıkmasına sebep olmuştur (Thakur, 2007, s. 83). Uzun zamandır üniversiteler için küresel bir karşılaştırmayı hedefleyen Academic Ranking of World Universities (ARWU), Times Higher Education World University Rankings, QSWorld University Rankings, U-Multirank, SCImago Institutions Rankings gibi sıralama sistemlerine son on yılda sürdürülebilirlik odaklı karşılaştırmalar eklenmeye başlanmıştır. $\mathrm{Bu}$ genel üniversite karşılaştırmaları temel olarak araştırma ve eğitim kapasitesine yoğunlaşırken, sürdürülebilirlik bakış açısıyla da, bir kurum olarak üniversitenin topluma ve çevreye etkisini de izlemeye başlamıştır.

Bahsedilen tüm bu genel ya da sürdürülebilirlik odaklı yaklaşımların geçerliliği, kapsamı, küresel bir anlayış sergileyebilmesi gibi konular üzerinde tartışmalar devam etmekle birlikte, bu sıralamaların üniversitelerin performanslarına sağladıkları çeşitli faydaları kabul edilmektedir (Marginson \& Van der Wende, 2007, s. 306; Lauder vd., 2015, s. 852; Suwartha \& Sari, 2013, s. 46). Son y1llarda bu tip üniversite 
sürdürülebilirlik sıralamalarının üniversite yönetişimi ve eğitim politikaları üzerinde de gözle görülür etkileri olmaya başlamıştır (Alshuwaikhat vd., 2017, s. 93; Marginson \& Van der Wende, 2007, s. 309). Bu nedenle, kullanılan yöntemler üzerine birçok eleştiri olmakla beraber, üniversitelerde sürdürülebilirlik kavramının içselleştirilmesi açısından bu sıralamalar önemlidir.

Yönetişim ve strateji çalışmalarının en önemli noktalarından biri ise stratejik iletişimdir. Çünkü hem iç paydaşlar hem de dış paydaşlar tarafından sürdürülebilirlik temel strateji ve politikalarının bilinir kılınması, bu çalışmaların etkinliğini daha da artırmaktadır. Uygun iletişim modelleri ile her bir paydaş grubuna ilgili politikaları benimsetmek ve farkındalık yaratmak, çalışmaların başarı kazanması ve toplumsal gelişimin sağlanması için en önemli basamaklardan biridir. Bir strateji geliştirmek, politika yapıcılar ve halk arasında da iki yönlü iletişim gerektirmektedir. Bu, bilgilendirme kampanyaları ve medya araçlanyla yapılan halkla ilişkiler girişimlerinden çok daha fazlasını gerektirmektedir. Sürdürülebilir kalkınma ve etkileri hakkında ortak bir anlayışa ulaşmak, zorluklara çözümler bulmak adına kapasite geliştirmeyi teşvik etmek için uzun vadeli sosyal etkileşim gerekmektedir (Rioplus, 2006, s. 20).

Sonraki bölümlerde, araştırma kapsamında incelenen Times Yüksek Öğretim Etki Sıralaması (Times Higher Education World University Rankings - THE Impact), IU GreenMetric Dünya Üniversite Endeksi (IU GreenMetric World University Ranking) ve Küresel Raporlama Girişimi - GRI raporlama standardına ilişkin bilgilere yer verilmekte, daha sonra örneklem dahilindeki endeksler karşılaştırılarak sürdürülebilir üniversite yönetişim ve stratejik alanlarının temel konuları ve iletişimi irdelenmektedir.

\subsection{THE Impact - Times Yüksek Öğrenim Etki Sıralaması (Times Higher Education Impact Rankings)}

Times Yüksek Öğrenim Etki Sıralaması (THE Impact), üniversiteleri Birleşmiş Milletler'in (BM) Sürdürülebilir Kalkınma Amaçlarına (SKA) uygun bir şekilde değerlendiren ve bu yolla üniversitelerin sürdürülebilir kalkınmaya etkilerini belirlemeyi hedefleyen performans bazlı yöntemdir (THE, 2020). BM SKA ise, SKA 1 - yoksulluğa son, SKA 2 - sıfır açlık, SKA 3 - sağlik ve esenlik, SKA 4 - kaliteli eğitim, SKA 5 - cinsiyet eşitliği, SKA 6 - temiz su ve sanitasyon, SKA 7 - ekonomik ve temiz enerji, SKA 8 insana yakışır iş ve ekonomik büyüme, SKA 9 - endüstri, yenilik ve altyap1, SKA 10 - azaltılmış eşitsizlikler, SKA 11 - sürdürülebilir şehirler ve topluluklar, SKA 12 - sorumlu tüketim ve üretim, SKA 13 - iklim eylemi, SKA 14 - suyun altında yaşam, SKA 15 - karada yaşam, SKA 16 - barış, adalet ve güçlü kurumlar, SKA 17 - hedefler için ortaklıklar başlıklarını içeren toplam 17 amaçtan oluşmaktadır (UNGC, 2020).

THE Impact için, üniversitelerin bilgileri, beyan usulüyle ancak kanıta dayalı şekilde yıllık bazda toplanmaktadır. Üniversiteler var olan göstergelerden, SKA 17 'hedefler için ortaklıklar' göstergeleri zorunlu olmak üzere, en yüksek puanı topladıklanı diğer üç SKA'dan puan almaktadırlar. SKA 17 toplam puanın \%22'sini oluştururken, diğer SKA'ların her biri \%26 ağırlı̆̆ındadır. BM SKA'ların üniversiteler için izdüşümü her amaç için araştırma, sosyal yardım ve yönetim alanlarında toplanabilecek göstergelerle belirlenmiştir. Burada sadece araştırma göstergeleri, üniversitelerin kendi beyanlarını değil, Elsevier tarafından sağlanan verilerden türetilmektedir. Farklı konuları içeren SKA'lar arasında seçim yapabilme esnekliği, farklı üniversitelerin odak alanlarına bağlı olarak farklı bir dizi SKA'ya göre puanlandığ1 anlamına gelmektedir. 2019 yilından beri yayınlanmakta olan THE Impact benzer siralamalar gibi sürekli bir güncellemeyi öngörmektedir (THE, 2020).

THE Impact sonuçlanını yıllık listelerken tüm üniversitelerin yer aldığı toplu bir liste yanında, SKA'lar bazında bir listeleme de yapmaktadır. Böylece her SKA için hangi üniversitelerin önde olduğu görülebilmektedir. Buna göre İklim Eylemi ile ilgili lider üniversiteler, Sürdürülebilir Eğitim ile ilgili üniversitelerden farklı olabilmektedir. The Impact sonuç listeleri, sıralamaya katılan üniversiteleri kent içi ya da dışı, büyük ya da küçük veya eski ya da yeni olarak ayırmamaktadır. Bu yöntemle THE Impact üniversiteler arasında bir uzmanlaşmaya da işaret etmektedir.

\subsection{IU GreenMetric Dünya Üniversite Endeksi}

IU GreenMetric Dünya Üniversite Endeksi (UI GreenMetric World University Ranking) (GreenMetric), Universitas Indonesia'nın 2010 yılında başlattı̆̆ı bir girişimidir. Bu sıralamanın amac1, dünyanın her yerindeki üniversitelerde Yeşil Kampüs ve Sürdürülebilirlik ile ilgili mevcut durum ve 
politikalara ilişkin durumu belirlemek, böylece küresel iklim değişikliği, enerji ve su tasarrufu, atık geri dönüşümü ve yeşil ulaşım ile ilgili konulardaki çabaya daha fazla önem verilmesini sağlamaktır. Bunun için kullanılan yöntem yılda bir kere üniversitelerin kanıta dayalı bir beyan yoluyla, belirlenen çevrimiçi bir ankete cevap vermeleridir. Verilere ilişkin kanıtlar, fotoğraflar, beyanlar ve diğer resmi belgeler içeren bir şablon kullanılarak toplanmaktadır (GreenMetric, 2020).

IU GreenMetric; 'üniversite peyzaj1 (yerleşim ve altyapı)'; 'elektrik tüketimi (enerji ve iklim değişikliği)'; 'attk yönetimi'; 'suyun korunması'; 'halk için yeşil ulaşım'; 'sürdürülebilirlik ile ilgili eğitim ve araştırma' olmak üzere 6 ana kritere dayanmaktadır. Endeks, aynı zamanda üniversitenin büyüklügünü ve kentsel, banliyö veya kırsal bölgelerindeki imar yapısını da dikkate almaktadır. Puanlamada Enerji ve İklim kriterinin ağırlığ $\% 21$ iken, Atık, Eğitim ve Ulaştırma \%18, Yerleşim ve Altyapı ağıllığ1 \%15'dir. En düşük olarak da \% 10 ile Su kriteri yer almaktadır. Toplanan sayısal veriler, kurumun çevre dostu ve sürdürülebilir politikalar ve programları uygulamak için gösterdiği çabaları yansıtan tek bir skora indirilmektedir.

2010 yllında dünya çapında 96 üniversitenin yer aldığı GreenMetric çalışması, 2019 yllında yine küresel olarak 780 üniversiteye ulamıştır. UI GreenMetric her yıl listeye dahil olan üniversiteleri genel bir sıralamanın yanı sıra bölgesel, ülke bazında, yerleşkenin kent içi ve dışı olması ve ayrıca yukarıda verilen 6 ana veri toplama kriterine göre sıralamaktadır. UI GreenMetric sıralamasında, üniversite büyüklüğü ve yaşı doğrudan etki yaratmamaktadır. GreenMetric benzer endeksler gibi her yil sıralamanın kriterlerini ve bunların detayını gözden geçirmektedir (GreenMetric, 2020). UI GreenMetric'in tüm katılımcıları otomatik olarak UI GreenMetric Dünya Üniversitesi Sıralama Ağına (UIGWURN) üye olmaktadır. Bu ağda katılımcılar bölgesel ve/veya ulusal çalıştaylar yolu ile en iyi uygulamalarını sürdürülebilirlik programlarında da paylaşabilmektedir.

\subsection{Global Raporlama Girişimi - GRI (Global Reporting Initiative)}

GRI (Global Reporting Initiative) - Global Raporlama Girişimi, 1997 yllında kurulan, sürdürülebilir raporlama ilkelerini belirlemede öncü olan bağımsız uluslararası bir organizasyondur. GRI, şirketlere ve hükümetlere ekonomik, çevresel ve sosyal ana başlıkları alında, kritik sürdürülebilirlik alanlarında etkilerini belirleyebilmelerini mümkün kılacak standartlar belirlemiştir. Sürdürülebilir gelişime katkıda bulunmak için ekonomik, çevresel ve sosyal alanları kapsayan konularda her sektörden şirkete ve hükümetlere rehberlik yapacak uluslararası standartlar çerçevesini ilk olarak 2000 yllında yayınlamışır. GRI daha sonra söz konusu standartları belirli yıllarda versiyonlar şeklinde revize etmiş ve ayrıca sektörlere özel ayrı rehberler yayınlamıştır (GRI, 2020a). GRI sürdürülebilir gelişim, ekonomik, sosyal ve çevresel ayaklarını içine alan üçlü bilanço sistemi (triple-bottom-line) sunan, pek çok şirket tarafindan tercih edilen ve edilmeye devam eden, en çok kullanılan uluslararası raporlama standardıdır. Yeni bir çerçeve geliştirilinceye kadar da bu yerini korumaya devam edecektir. Böyle bir senaryoda dahi, yine de önemli bir yer tutmaya devam edecektir (Hohnen, 2012, s. 5, 14).

GRI çerçevesi, herhangi bir kuruluşun sürdürülebilirlik performansını ölçmek ve raporlamak için kullanabileceği ilke ve göstergeleri belirlemektedir. Ayrıca, farklı büyüklük ve sektördeki şirketlere süreci ne şekilde yürüteceklerine rehberlik etmektedir. GRI yönergeleri bu nedenle şirketlerin kamuya açı sürdürülebilirlik raporlarını yayınlamaları için kullanabileceği küresel bir standarttır. GRI rehberini kullanarak şirketler; paydaşlarının beklentilerini kapsayan kilit konuları ele almakta, bu alandaki uzmanlar tarafindan kabul edilen performans hesaplama araçları için gerekli gösterge ve metotları kullanmakta; rakipleriyle kıyaslama yapmasını sağlayacak bir raporlama yapabilmektedir. Kılavuz ayrıca, ekonomik, sosyal, çevresel performanslar ile iş operasyonları ile tedarikçilerle katılımı kapsayan yönetişime ilişkin temel strateji ve sistemlerin incelenmesini mümkün kilmaktadır (IFC, 2010, s. 5).

GRI'nn başarılı olmasının nedenleri arasında: bu konudaki ilk girişim olması; dünyanın dört bir yanından hükümet ve iş dünyası dahil pek çok paydaşın katılımı ile gerçekleştirilmesi; sektöre özel sunulan özel sektör yönerge ve tavsiyelerinin olmasi; raporlama kriterlerinde sürekli gözden geçirme ve iyileştirmeler yapması; kullanıcıların öncelikli sorunlanı tanımlamasına ve öncelikli konular yaklaşımına odaklanmasını sağlaması; ve bununla birlikte GRI çerçevesinin en yaygın kullanılan, BM Küresel İlkeler Sözleşmesi, OECD Çok Uluslu Şirketler için Yönergeler ve ISO 26000 Sosyal Sorumluluk Rehberlik Standardı gibi küresel kurumsal sorumluluk çerçevesini tamamlayıcı nitelikte olması bulunmaktadır 
(Hohnen, 2012, s. 5). Alshuwaikhat vd.'ne (2017, s. 97) göre, GRI'a katılan üniversite say1s1 2011'den 2016 ya \%600 artmıştır. 2020 y1lında ise GRI raporlaması yapan onaylı 131 üniversite bulunmaktadır (GRI, 2020b).

\section{Endeks Ve Raporlama Bazlı Yönetişim ve Strateji Yaklaşımı Önerisi}

Yönetişim; birbirine bağlı ve karmaşık sorunların yönetilme biçimine atıfta bulunmak için hemen hemen her uluslararası kuruluşta ve demokratik hükümette yerleşik olarak oldukça yaygin kullanılan bir kavramdır. Yönetişim kavramı kimin ve hangi bağlamda kullanıldığına bağlı olarak farklı şeyler ifade etmektedir. En temel anlamıyla yönetişim, kamu, özel ve kâr amacı gütmeyen aktörlerin kamu politikalarını oluşturmak ve uygulamak için etkileşimde bulunduğu etkileşimli bir fenomen olarak ifade edilebilir (Ysa, vd., 2014, s. 1, 11). Yap1 olarak yönetişim; resmi ve gayri resmi kurumların mimarisini ifade etmekte; bir süreç olarak uzun ve asla bitmeyen politika oluşturma süreçlerinde yer alan dinamikleri ve yönlendirme işlevlerini belirtmekte; bir mekanizma olarak uygunluk ve denetime ilişkin kurumsal karar alma prosedürlerini ifade etmekte; son olarak, bir strateji olarak, seçim ve tercihleri şekillendirmek için önemli aktörlerin kurumların ve mekanizmaların tasarımını yönetme ve manipüle etme etkilerini ifade etmektedir (Levi-Faur, 2012, s. 8). Strateji ise, en genel tanımıla bir amaca nasıl ulaşılacağıyla ilgilidir. Strateji, taktiklerle birlikte amaçlarla araçlar arasındaki boşluğu doldurmaktadır. Ulaşılacak amaçların belirlenmesi gerçekten de stratejik düşünmeyi gerektirir, ancak bunları gerçekleştirecek stratejiye karar vermekten ayrı tutulmalidir (Nichols, 2008, s. 4).

Çalışmada THE Impact, GRI ve GreenMetric sürdürülebilirlik endeksleri yönetişim ve strateji açısından karşılaştırmalı olarak detaylı şekilde incelenmiş ve ele aldıkları göstergeler açısından analiz edilmiştir. Çalışma, üniversitelerin sürdürülebilir yönetişim ve strateji açısından, sürdürülebilirlik derecelendirme endekslerine göre karşılaştırmalı bir analizi bugüne dek yapılmadığından, literatüre katkı sağlaması açısından önem taşımaktadır. Bununla birlikte, belirtilen endeks standartları her y1l güncellendiği için, çalışmanın ilerleyen yıllarda gözden geçirilerek tekrar değerlendirilmelerinin yapılması ve yeni çalışmaların literatüre eklenmesi gerekmektedir.

Araştırma kapsamında analiz edilen üç farklı endeksin içeriği göz önünde bulundurulduğunda üniversitelerin sürdürülebilirlik yönetişimi ve strateji konusunda Tablo 1'de gösterildiği üzere; 'Temel Strateji ve Politikalar/Yönetim Yapısı', 'Etik', 'Sosyal Alanlar: Cinsiyet Eşitliği - Eşitlik ve Çeşitlilik - İnsan Hakları', 'Çevresel Etki Politikaları' ana başlıkları altında sınıflandırılabileceği ortaya çıkmıştır.

Tablo 1. Sürdürülebilir Üniversite Yönetişim Ve Strateji Yaklaşımı Önerisi Başlıkları

\begin{tabular}{l} 
Yönetişim ve Strateji \\
1. Temel Strateji ve Politikalar/Yönetim Yapısı \\
2. Etik \\
3. Cinsiyet Eşitliği - Eşitlik ve Çeşitlilik - İnsan Hakları \\
4. Çevresel Etki Politikaları \\
\hline
\end{tabular}

\subsection{Temel Strateji ve Politikalar/Yönetim Yapısı}

Endekslerin incelemesi sonucunda Yönetişim ve Strateji başlı̆̆ının ilk sınıfını kurumun yönetilmesine dair temel strateji ve politikalar ile yönetim yapısının oluşturduğu ortaya çıkmıştır. Bu çerçevede, Tablo 2'de görüldüğü üzere ana stratejiler kısmında GRI ilk etapta; kurumun üst düzey yöneticilerinin strateji ve politikalara yönelik beyanını sorgulamakla birlikte, kurumun temel etki, risk, firsatlarını, yönetim yaklaşımını, kurumun öncelikli konularını nelere göre belirlediğini ve bu öncelikli konuların neler olduğunu sorgulamaktadır. Bununla birlikte, kurumun temel yapısını oluşturan bu konuları THE Impact ${ }^{1}$ direkt olarak sorgulamamaktadir.

Paydaş yönetimi ve katılımı ise sürdürülebilirlik alanının en temel kavramlarının başında gelmekte ve tüm çalışmaların temel dinamiğini oluşturmaktadır. Bu nedenle paydaş katılımı her iki endekste de detaylı bir şekilde ele alınmaktadır. GRI ve THE Impact'in her ikisi de kurumun paydaşlarını ne şekilde belirlediğini, paydaşlarının kimler olduğunu ve paydaşların yönetim kararlarına ne derece katıldığını

\footnotetext{
${ }_{1}^{1}$ GreenMetric bu alanda sadece 4 performans sorguladığı için çalışmada yapılan karşılaştırmalar GRI ve THE Impact'e refere edilecek, sadece ilgili performanslar söz konusu olduğunda GreenMetric’e referans verilecektir.
} 
sorgulamaktadır. GRI her bir paydaş grubuna özel paydaş katılım diyaloglarını kapsamlı bir şekilde sorgularken; THE Impact endeksinde üniversiteler kapsamında öne çıan konu öğrencilerden, fakülteden ve personelden yönetim temsiliyet oranları, öğrenci birliklerinin tanınması gibi her paydaş özelinde yapılan çalışmalardır. GreenMetric ise paydaş katılımı kapsamında sadece çevre ve sürdürülebilirlikle ilgili çalışan öğrenci kulüplerinin varlığını sorgulamaktadır².

Kurumun kamu politikası yaklaşımı, kurumların yaptıkları iş birlikleri, üyelikleri de yine her iki endeks tarafından sorgulanmaktadır. THE Impact burada farklı olarak hükümet SDG politika gelişimine doğrudan dahil olma veya bunlara girdi sağlamaya yönelik girişimleri ve üniversite genelinde, bazı programlarda veya tüm programlarda SDG'ler hakkında anlamlı eğitim taahhütlerini de sorgulamaktadır. Temel strateji ve politikalar kapsamında ele alınabilecek bir diğer konu sağlık ve güvenliğe ilişkin yönetim yaklaşımıdır. GRI konuyu ürün sağlık ve güvenliği çerçevesinde kurumlar özelinde ele almaktadır. Bu uygulamaların bir kısmını üniversite hizmetlerine uygulamak mümkün olsa da, THE Impact'in bu konudaki 'sağlık etkisi ve kamu sağlığını artırmak için yapılan yerel, ulusal ya da uluslararası ortaklıklar, sigara karşıtı politikalar' olarak belirlediği göstergeler sürdürülebilir üniversite kapsamında daha uygulanabilirdir.

Sürdürülebilirlik raporu yayınlayıp yayınlamadığı ise her üç yöntemin de sorguladığı bir göstergedir. Bu konuda her üç endeksin de birbirini tamamladığı ileri sürülebilir. GRI sürdürülebilirlik komite ve çalışmalarını çok detaylı irdelemekle birlikte, THE Impact bu konunun detaylarını ele almamaktadır. GRI, THE Impact'den farklı olarak, kurumun yönetişim organının yapısı, komiteleri, seçim yöntemleri, performans değerlendirmesi, ücretlendirilmesi, yönetim kurulu organının çevresel, ekonomik, sosyal alanlardaki uzmanlıkları ve sürdürülebilirlik çalışmalanındaki rollerini sorgulamaktadır. GreenMetric ise Tablo 2'de de belirtildiği üzere, sadece üniversitenin sürdürülebilirlik çalışmaları için ayrılan bütçesini sormaktadır. Son olarak GRI, diğer endekslerden farklı olarak bu çerçevede yasa ve yönetmeliklere de uyum sağlanıp sağlanmadığını kontrol etmek için bunlara aykııı bir vaka yaşanıp yaşanmadığını ve ödenen cezaları sorgulamaktadır.

Tablo 2. Yönetişim ve Strateji: Temel Strateji ve Politikalar/Yönetim Yapısı

\begin{tabular}{|c|c|c|}
\hline GRI & THE IMPACT & GREENMETRIC \\
\hline $\begin{array}{c}\text { Temel Strateji ve } \\
\text { Politikalar/Yönetim Yapısı }\end{array}$ & $\begin{array}{c}\text { Temel Strateji ve } \\
\text { Politikalar/Yönetim Yapısı }\end{array}$ & $\begin{array}{c}\text { Temel Strateji ve } \\
\text { Politikalar/Yönetim Yapısı }\end{array}$ \\
\hline $\begin{array}{l}\text { Üst düzey yönetici beyanı ve } \\
\text { stratejisi/Temel etkiler, riskler } \\
\text { firsatlar (102-14, 102-15) }\end{array}$ & - & - \\
\hline $\begin{array}{l}\text { Öncelikli konuların ve sınırlarının } \\
\text { açıklaması/Öncelikli konular listesi } \\
(102-47)\end{array}$ & - & \\
\hline $\begin{array}{c}\text { Paydaşların tanımlanması ve } \\
\text { seçimi/Paydaş katılım } \\
\text { yaklaşımı/Paydaş listesi (102-40, } \\
\text { 102-42, 102-43) }\end{array}$ & $\begin{array}{l}\text { Yerel halk, yerel yönetim, özel, sivil } \\
\text { toplum temsilcileri de dahil olmak } \\
\text { üzere yerel paydaşları tanımak ve } \\
\text { paydaş katılımını sağlamak için } \\
\text { katılımcı organların varlığı/Konuyla } \\
\text { ilgili yazılı politika ve prosedürler } \\
\text { (SDG 16-16.2.3. ve 16.2.4.) }\end{array}$ & - \\
\hline $\begin{array}{c}\text { Paydaşlara } \\
\text { ekonomik/çevresel/sosyal } \\
\text { konularda danışma mekanizması ve } \\
\text { paydaşların yönetimde temsil } \\
\text { şekilleri }(102-21,102-37,102-44)\end{array}$ & $\begin{array}{l}\text { Üniversitenin en yüksek yönetişim } \\
\text { organını temsilen öğrencilerden } \\
\text { (okuyan ve mezun), fakülteden, } \\
\text { personelden seçilen kişiler (SDG } 16 \\
-16.2 .1 .)\end{array}$ & - \\
\hline- & $\begin{array}{l}\text { Öğrenci birliklerinin tanınması } \\
\text { (SDG } 16-16.2 .2 .)\end{array}$ & $\begin{array}{c}\text { Çevre ve sürdürülebilirlikle ilgili } \\
\text { çalışan öğrenci kulüpleri (Ĕgitim ve } \\
\text { Araşturma / 5) }\end{array}$ \\
\hline Kurumun ihtiyadi yaklaşımı/Kamu & STK'lar, yerel ve ulusal hükümetlerle & - \\
\hline
\end{tabular}

\footnotetext{
2 Greenmetric bu çerçevede sadece 4 performans sorguladığı için, bu bölümdeki ilk tablodan sonraki tablolarda GreenMetric kolonu yer almamaktadır.
} 


\begin{tabular}{|c|c|c|}
\hline $\begin{array}{l}\text { politikası (102-11)/Siyasi partilere, } \\
\text { politikacılara ve ilgili kuruluşlara } \\
\text { yapılan katkılar (415-1)/Devletten } \\
\text { alınan finansal destekler (201-4) }\end{array}$ & $\begin{array}{c}\text { ilişkiler/Ulusal hükümet SDG } \\
\text { politika gelişimine doğrudan dahil } \\
\text { olma veya bunlara girdi sağlama } \\
\text { (SDG } 17 \text { - 17.2., } \\
\text { 17.2.1.)/Yoksullukla mücadele için } \\
\text { yerel, bölgesel, ulusal-uluslararası } \\
\text { programların uygulanmasına ilişkin } \\
\text { kamu politikalarına katılım } \\
\text { çalışmalarına katıllım (SDG 1-1.4.4.) }\end{array}$ & \\
\hline $\begin{array}{l}\text { Diş girişimler/Üyelikler (102-12, } \\
\text { 102-13) }\end{array}$ & $\begin{array}{l}\text { SDG'ler ile ilgili sektörel diyalog } \\
\text { platformlarına katılım girişimleri } \\
\text { (Hükümet ve STK'lar dahil) (SDG } \\
17-17.2 .2 .)\end{array}$ & - \\
\hline - & $\begin{array}{c}\text { Üniversite genelinde, bazı } \\
\text { programlarda veya tüm } \\
\text { programlarda SDG'ler hakkında } \\
\text { anlamlı eğitim taahhütleri (SDG } 17 \\
\text { - 17.4.1.) }\end{array}$ & - \\
\hline $\begin{array}{l}\text { Ürün sağlık ve güvenliğine ilişkin } \\
\text { politikalar (Bilgi gizliliği, etiketleme } \\
\text { ve pazarlama iletişimi konuları dahil) } \\
\text { (416-1, 417-1)/Bu konularla ilgili } \\
\text { yasalara uygun olmayan vakalar } \\
(416-2,417-2,417-3,418-1)\end{array}$ & $\begin{array}{c}\text { Sağlık etkisi/Kamu sağlığını } \\
\text { artırmak için yapılan yerel, ulusal ya } \\
\text { da uluslararası ortaklıklar/Sigara } \\
\text { karşıtı politikalar (SDG 3-3.3.1., } \\
\text { 3.3.6.) }\end{array}$ & - \\
\hline $\begin{array}{c}\text { Sürdürülebilirlik raporlaması (102- } \\
\text { 45, 102-46, 102-48, 102-49, 102-50, } \\
\text { 102-51, 102-52, 102-53, 102-54, } \\
102-55,102-56)\end{array}$ & $\begin{array}{c}\text { Sürdürülebilirlik } \\
\text { raporlamas1/SDG'lere göre } \\
\text { yayınlanan sürdürülebilirlik raporlar1 } \\
\text { (SDG } 17 \text { - 17.3.1., SDG 12-12.4.1.) }\end{array}$ & $\begin{array}{l}\text { Yayınlanan sürdürülebilirlik } \\
\text { raporları/Üniversitenin } \\
\text { sürdürülebilirlik İnternet sitesi } \\
\text { (Eğitim ve Araştırma / 6,7) }\end{array}$ \\
\hline $\begin{array}{c}\text { Yönetişim yapısı/Kurullar- } \\
\text { komiteler/Yönetimin } \\
\text { sürdürülebilirlik çalışmalarındaki } \\
\text { rolü/Yönetim Kurulu uzmanlıkları, } \\
\text { ücretlendirilmesi ve performans } \\
\text { yönetimi }(102-18,102-19,102-20, \\
\text { 102-21, 102-22, 102-23, 102-24, } \\
\text { 102-26, 102-27, 102-28, 102-29, } \\
\text { 102-30, 102-31, 102-32, 102-33, } \\
\text { 102-34, 102-35, 102-36, 102-38, } \\
102-39)\end{array}$ & $e_{1}$ & $\begin{array}{c}\text { Üniversitenin sürdürülebilirlik } \\
\text { çalışmaları için ayrılan bütçesi } \\
\text { (Yerleşim ve Altyapı / G) }\end{array}$ \\
\hline $\begin{array}{c}\text { Yasa ve yönetmeliklere uyulmamas1 } \\
\text { nedeniyle açılan davalar/Ödenen } \\
\text { cezalar (419-1, 307-1) }\end{array}$ & - & - \\
\hline
\end{tabular}

Temel Strateji ve Politikalar/Yönetim Yapısı kapsamında değerlendirildiğinde, sürdürülebilirlik raporlaması alanında her üç endeksin de birbirini tamamladığı görülse de, THE Impact, tüm SDG’leri içeren bir endeks olmasına rağmen, GRI gibi üniversite içindeki yönetişim ve sürdürülebilir yönetim yapısını sorgulamamaktadır. Ayrıca bu konudaki risk ve firsatlar ile öncelikli konuları da sorgulamaması, endeksin iki önemli eksiği olarak ortaya çıkmaktadır. GRI ise her konudaki stratejiyi genel çerçevede sorgulamakta, üniversite özeline indirebilecek noktaları içermemesi açısından eksik kalmaktadır. GreenMetric ise bu çerçevede sadece öğrenci kulüplerini ve raporlama göstergelerini almış, diğer noktalarda eksik kalmıştır.

\subsection{Etik}

Yönetişimin en önemli unsurlarından bir diğeri ise etik ve dürüstlük konusudur. Etik, felsefenin iyi yaşamakla, iyi bir insan olmakla, doğru şeyi yapmakla, diğer insanlarla iyi geçinmekle ve hayatta doğru şeyleri istemekle ilgilenen kısmıdır. "Etik" kelimesi, hem bir disiplini - değerlerimizi ve onların gerekçelerini 
incelemeyi - hem de bu disiplinin konusunu - içinde yaşadı̆̆ımız gerçek değerleri ve davranış kurallarını ifade etmektedir. Isş etiği ise, ekonomik eylemleri dikkate alarak etik değerlendirme yoluyla ekonomik rasyonalite kavramını genişletmeye çalışmaktadır. İş etiği, etik ekonomik teorilerin temelini belirleyerek değil, aynı zamanda ekonomik eylemin karşılaması gereken etik kriterleri formüle ederek ve gerekçelendirerek de kuralcı bir şekilde hareket etmektedir (Zimmerli, Richter \& Holzinger, 2007, s. 12, 38).

Etik kavramı sürdürülebilirlik içinde önemli bir yer teşkil etmektedir. GRI bu konuyu etik kodlar, etik hat, kurum içi etik sebeplerden kaynaklı riskler çerçevesinde ele almakta ve oldukça detaylı bir şekilde sorgulamaktadır. Yolsuzluğa karşı alınan önlemler, tedarikçilere yönelik uygulamalar, çıkar çatışmasını önleme mekanizmaları, etik ile ilgili verilen eğitimler yine bu başlık altında ele alınan göstergelerdir. THE Impact ise, üniversitelerin etik iş süreçlerini doğrudan sorgulamamakta, ancak suç, yolsuzluk ve rüşvete yönelik yayınlanmış ilkeler ve taahhütleri ele almaktadır.

Tablo 3. Yönetişim ve Strateji: Etik

\begin{tabular}{|c|c|}
\hline GRI & THE IMPACT \\
\hline Etik & Etik \\
\hline $\begin{array}{c}\text { Yolsuzluğa karşı alınan önlemler/Analiz } \\
\text { edilen iş birimleri sayıs1/Çıłkar çatş̧ması (102- } \\
25,205-1)\end{array}$ & $\begin{array}{c}\text { Suç, yolsuzluk ve rüşvete yönelik yayınlanmış } \\
\text { ilkeler ve taahhütler (SDG 16-16.2.5.) }\end{array}$ \\
\hline $\begin{array}{c}\text { Yolsuzluk ve etikle ilgili verilen eğitimler } \\
(205-2)\end{array}$ & - \\
\hline $\begin{array}{c}\text { Değerler, ilkeler, standartlar ve davranış } \\
\text { kuralları/Etikle ilgili iç mekanizmalar (102-16, } \\
102-17)\end{array}$ & - \\
\hline $\begin{array}{c}\text { Tekelcilik ve yolsuzlukla ilgili açılan davalar } \\
(205-3,206-1)\end{array}$ & - \\
\hline
\end{tabular}

Etik ana başlığ1 altında, GRI konuyu kurumların tüm iş yapış süreçlerindeki etiğe yönelik alınan önlemler, mekanizmalar ve uygulamalar, eğitimler olarak kapsamlı bir şekilde ele almaktadır. Bununla beraber THE Impact endeksinin konuya çok fazla vurgu yapmaması ve süreçleri etik kapsamında değerlendirmemesi endeksin eksikliği olarak ortaya çıkmaktadır.

\subsection{Sosyal Alanlar: Cinsiyet Eşitliği - Eşitlik ve Çeşitlilik - İnsan Hakları}

Ulusal ve küresel düzeyde sürdürülebilir ekonomik büyümenin sağlanabilmesi kadınlann iş gücüne katılması ve beceri ve yeteneklerini tam kapasiteleri ile kullanabilmelerine bağlıdır (OECD, 2008, s. 11). Bunun mümkün olabilmesi de cinsiyet eşitliğini gerekli kılmaktadır. Bununla birlikte eşitlik sadece cinsiyete indirgenemeyecek kadar önemli bir konudur. Dünya çapında artan eşitsizlikler, zamanımızın önemli bir sorunu haline gelmiştir. Hem ülkelerin kendi içinde hem de ülkeler arasındaki büyük eşitsizlikler sürdürülebilir kalkınmayı riske atmakta, sosyal huzursuzluğu körüklemekte, sosyal ilerlemeyi baltalamakta, ekonomik ve siyasi istikrarı tehdit ederek, insan haklarını riske atmaktadır (UN, 2016, s. 1). Toplumsal gelişimin sağlanması ancak tüm bireylere eşit haklar tanınması, insan haklarına tam uyum sağlanması ve çeşitlilik politikaları ile mümkündür. Bu nedenle söz konusu konular sürdürülebilirlik çalışmalarının içinde önemli bir yer teşkil etmektedir. Üniversiteler ise toplumun yönderliğini yapan eğitim-öğretim kurumları olarak bu konudaki strateji ve politikalarıyla örnek olma misyonu taşımaktadırlar.

THE Impact eşitlik ve çeşitlilik konusunu farklı başlıklar altında ele almaktadır. Endekste; kadın-erkek eşitliği 13 madde, çeşitlilik 10 madde, insan hakları 4 madde olarak listelenmiştir. GRI da, THE Impact de cinsiyet eşitliği konusunu oldukça kapsamlı ele almaktadır. THE Impact; üniversiteye yapılan kadın başvuru sayısının artırılmasından, kadınların tüm süreçlere dahil edilmesine yönelik politikalar, kadınların her alanda desteklenmesine yönelik yönetim yaklaşımı ile üst düzey kadın akademisyen sayısı gibi üniversiteye özel kriterleri göstergeleri arasına alırken, GRI da, başta fırsat eşitliği ve çeşitlilik yönetim yaklaşımı olmak üzere, aynı içerikte tüm kurumları kapsayacak bilgileri bu kapsamda genel çerçevede sorgulamaktadır. Kadın-erkek maaşları arasındaki farkın kapanmasına yönelik politikalar; annelik ve babalık haklan uygulamaları da bu kapsamda her iki endekste de ele alınmaktadır. Üniversite kapsamında bu alanda 
öne çıkan konu ise THE Impact kapsamında sorgulanan yeni annelerin üniversite eğitimine başlamasına yönelik sunulan imkânlardır.

Eşitlik ve Çeşitlilik başlğ̆1 altında ise; ayrımcllığı önlenmesi ve çeşitlilik yönetim yaklaşımı ve politikaları, bu konuda alınan önlemler; konuyla ilgili komitelerin varlığı; dezavantajlı grupların eşit haklar elde etmesine yönelik çalışmalar sorgulanmaktadır. GRI bu kısmı detaylandırmamış gibi gözükse de, THE Impact'in Tablo 4'de özellikle belirttiği tüm başlıkları kapsayacak bilgileri alt içeriğinde istemektedir. Bununla birlikte üniversiteler özelinde, THE Impact Tablo 4'de görüldüğü üzere, eğitim ve istihdam dezavantajı yaratan ayrımcıllı̆̆ engellemeye yönelik politikaları, yetersiz kaynaklara sahip bireylere yönelik yapılan çalışmaları öne çıkarmaktadır.

İnsan Haklarına ilişkin maddeler ise, THE Impact'de SDG'lerin insana yakışır iş ve ekonomi maddesi altında sınıflandırılmıştur. Bu kapsamda üniversitenin iş̧̧i hakları, toplu iş sözleşmesi vb. sözleşmeleri destekleyen birlikleri tanıması ve üyelikleri; çocuk işçi, zorla işçiliği engellemeye yönelik politikalar; tedarikçilerin çalışanlarına eşit haklar sağlandığının kontrol edilmesine yönelik politikalar; çalısan haklarına ilişkin süreçler her iki endekste de yer almaktadır. Bu açıdan her iki endeks de birbirini tamamlamaktadır. İnsan Hakları başlığında GRI ayı zamanda yerel halkın haklarına yönelik yönetim yaklaşımını ve alanda imzalanan anlaşmaları da sorgulamaktadır. THE Impact ise, bu alanda akademik özgürlügü destekleme politikasına vurgu yapmaktadır. Tüm bunlara ek olarak eşit firsatlar kapsamında toplumun gelişimine yönelik olarak THE Impact üniversitenin sanat ve kültürel mirasın desteklenmesi için yaptuğı çalışmalanı ve bu kapsamdaki harcamalarını sorgulamaktadır.

Tablo 4. Yönetişim ve Strateji: Sosyal Alanlar: Cinsiyet Eşitliği - Eşitlik ve Çeşitlilik - İnsan Hakları

\begin{tabular}{|c|c|}
\hline GRI & THE IMPACT \\
\hline Cinsiyet Eşitliği & Cinsiyet Eşitliği \\
\hline $\begin{array}{l}\text { Fırsat eşitliği ve çeşitlilik yönetim yaklaşımı } \\
\qquad(103-1,103-2,103-3)\end{array}$ & $\begin{array}{c}\text { Cinsiyet eşitliğini sağlamaya yönelik önlemler/Kadına karş1 } \\
\text { ayrımcllığa yönelik politikalar (SDG5-5.2., 5.6.1.) }\end{array}$ \\
\hline $\begin{array}{c}\text { Kadın istihdamını artırmaya yönelik } \\
\text { politikalar/Çalışanların yaş, cinsiyet, azınlık } \\
\text { grubu dökümü (405-1) }\end{array}$ & $\begin{array}{l}\text { Üniversiteye yapılan kadın başvuru, giriş ve mezuniyet oranlarını } \\
\text { sistematik olarak takip etme mekanizmaları - Bu oranları } \\
\text { artırmaya yönelik uygulanan politikalar (SDG5-5.3.1., 5.3.2., } \\
\text { 5.6.6., 5.6.7.)/ Kadın erişimini ve temsil edilmediği alanları } \\
\text { destekleyen yaklaşım ve uygulamalar (SDG5- 5.3.3., 5.3.4.) }\end{array}$ \\
\hline $\begin{array}{l}\text { Kadın-erkek çalışan/işe alım/terfi oranları } \\
\qquad(405-1)\end{array}$ & Kadın senyör akademisyen oranı (SDG5-5.4.1.) \\
\hline $\begin{array}{c}\text { Çalışan kategorisine göre erkek-kadın maaş } \\
\text { Oranları (405-2) }\end{array}$ & $\begin{array}{l}\text { Kadın-erkek maaşları arasındaki farkın kapanmasına yönelik } \\
\text { politikalar (SDG8-8.2.6.) }\end{array}$ \\
\hline $\begin{array}{c}\text { Anne-bebek politikası yönetim } \\
\text { yaklaşımı/Cinsiyet kııılımlı olarak doğum iznine } \\
\text { ayrılan çalışanların sayısı ve işe geri dönüş oranı } \\
\text { (401-3) }\end{array}$ & $\begin{array}{c}\text { Kadın katılımını artırmak ve desteklemek için annelik ve babalık } \\
\text { hakları uygulamaları/Üniversite personeli için sunulan çocuk } \\
\text { bakım hizmetleri (SDG5- 5.6.3., 5.6.5.) }\end{array}$ \\
\hline $\begin{array}{l}\text { Anne-bebek politikası kapsamında yapılan } \\
\text { çalışmalar/Doğum izni (401-3) }\end{array}$ & $\begin{array}{l}\text { Yeni annelerin üniversite eğitimine başlamaları için sunulan } \\
\text { çocuk bakım hizmetleri (SDG5- 5.6.4.) }\end{array}$ \\
\hline
\end{tabular}

\begin{tabular}{|c|c|}
\hline Eşitlik ve Çeşitlilik & Eşitlik ve Çeşitlilik \\
\hline $\begin{array}{l}\text { Ayrımcılığın önlenmesi yönetim yaklaşımı (103- } \\
\qquad 1,103-2,103-3)\end{array}$ & $\begin{array}{l}\text { Etnik köken, engellilik, cinsiyet gözetmeksizin eğitim } \\
\text { faaliyetlerine ulaşımı mümkün kılan politika (SDG4- } \\
\text { 4.3.5.)/İsyerinde aynımcllı̆̆ engellemeye yönelik politikalar (din, } \\
\text { cinsel tercih, cinsiyet ve yaş dahil olmak üzere) (SDG8- } \\
\text { 8.2.3.)/Ayrımcilığa ve temsiliyet oranı düşük gruplara yönelik } \\
\text { alınan önlem ve uygulamalar (SDG 10-10.6., } \\
\text { 10.6.1.)/Transgender bireylere karşı ayrımcllı̆a yönelik politikalar } \\
\text { (SDG5-5.6.2.) }\end{array}$ \\
\hline $\begin{array}{l}\text { İs yerinde ayrımcıllğı önlemeye yönelik politika } \\
\text { ve çalışmalar }(103-1,103-2,103-3)\end{array}$ & $\begin{array}{l}\text { Pozitif ayrımcılık politikalarını uygulama politikaları (SDG10- } \\
\text { 10.6.1.)/Ayrımcılık ve taciz karşıtı politikalar (SDG10-10.6.4.) }\end{array}$ \\
\hline - & $\begin{array}{c}\text { Eğitim ve istihdam dezavantajı yaratan ayrımcillğ1 engellemeye } \\
\text { yönelik politikalar (SDG5- 5.6.8.) }\end{array}$ \\
\hline- & Çeşitlilik ve eşitlik komitesi ve politika önermek ve uygulamak, \\
\hline
\end{tabular}




\begin{tabular}{|c|c|}
\hline & $\begin{array}{c}\text { program yönetmek, çeşitlik-eşitlik ve kampüste insan haklarıyla } \\
\text { ilgili eğitimler düzenlenmek için ofis ve konuyla ilgili çalışanının } \\
\text { olup olmadığ1 (SDG10-10.6.4.) }\end{array}$ \\
\hline- & $\begin{array}{c}\text { Yetersiz kaynaklara sahip gruplar dahil olmak üzere engelli } \\
\text { bireyler için makul barınma politika ve stratejileri (SDG10- } \\
10.6 .10 .)\end{array}$ \\
\hline
\end{tabular}

\begin{tabular}{|c|c|}
\hline İnsan Hakları & İnsan Hakları \\
\hline İnsan hakları politikası $(103-1,103-2,103-3)$ & $\begin{array}{c}\text { Akademik özgürlüğü destekleme politikası (Araştırma alanlarını } \\
\text { seçme ve araştırma alanı hakkında kamuya açık konuşma ve } \\
\text { öğretme özgürlüğü) (SDG 16-16.2.6.) }\end{array}$ \\
\hline $\begin{array}{c}\text { İnsan haklarılya ilgili imzalanan/taraf olunan } \\
\text { sözleşme sayısı }(412-1,412-3)\end{array}$ & - \\
\hline $\begin{array}{l}\text { Toplu iş sözleşmesine tabi çalışanların oranı } \\
\qquad(102-41)\end{array}$ & $\begin{array}{c}\text { Üniversitenin işçi hakları, toplu iş sözleşmesi vb. sözleşmeleri } \\
\text { destekleyen birlikleri tanıması ve üyelikleri (Kadın ve uluslararası } \\
\text { personel dahil) (SDG8-8.2.2.) }\end{array}$ \\
\hline $\begin{array}{l}\text { Çocuk ve zorla işçi çalışıtırlmasına yönelik } \\
\text { yönetim yaklaşım (103-1, 103-2, 103-3) }\end{array}$ & $\begin{array}{c}\text { Çocuk işçi, zorla işçi, modern köleliği engellemeye yönelik } \\
\text { politikalar (SDG8-8.2.4.) }\end{array}$ \\
\hline $\begin{array}{l}\text { Tedarikçilerin sosyal değerlendirmesi yönetim } \\
\text { yaklaşımı }(103-1,103-2,103-3,414-1)\end{array}$ & $\begin{array}{c}\text { Tedarikçileri çalışanlarına eşit haklar sağlandığının kontrol } \\
\text { edilmesine yönelik politikalar (SDG8-8.2.5.) }\end{array}$ \\
\hline $\begin{array}{l}\text { Yerli halkın haklarının ihlaliyle sonuçlanan } \\
\text { vakaların toplam sayısı ve alınan önlemler (411- }\end{array}$ & $\begin{array}{c}\text { Çalışanların, çalışan hakları ve ödemelerine itiraz etmelerine } \\
\text { yönelik süreçler (SDG8-8.2.8.) }\end{array}$ \\
\hline- & $\begin{array}{c}\text { Sanat ve kültürel mirasın desteklenmesi için yapılan harcamaların } \\
\text { oranı (SDG11-11.3.1.)/Sürdürülebilir pratikler (SDG11-11.4.) }\end{array}$ \\
\hline
\end{tabular}

Cinsiyet eşitliği konusunda her iki endeksin de oldukça kapsamlı sorgulama yapması noktasında birbirini tamamladığı görülmektedir. Bununla birlikte GRI sorularını daha genel çerçevede sormakta, THE Impact'in yaptığı gibi üniversiteye özel soruları bulunmamaktadır. THE Impact'de ise, GRI'ın sorduğu gibi üniversite çalışan kadın çalışan sayısı, kadınların terfi oranlarını sorgulamayarak kurum içi cinsiyet eşitliği alanında eksiklik göstermektedir. Eşitlik ve Çeşitlilik başlğı altında, GRI konuyu daha genel çerçevede ele almakta, THE Impact ise eğitim ve istihdam dezavantajı yaratan konular dahil olmak üzere konuyla ilgili üniversitelerde olması gereken konuları ele almıştır. Bu açıdan herhangi bir eksik nokta olmadığ1 ileri sürülebilir. İnsan Hakları başlığı altında ise insan haklarına ilişkin belli başlı konuların tümü ele alınmakla birlikte, üniversitelerin hem kendisi hem de toplumsal gelişime katkıda bulunmak için gerekli olan insan hakları eğitimlerini sorgulamamaları her iki endeksin de eksik noktası olarak ortaya çımaktadır.

\section{4. Çevresel Etki Politikaları}

Bir kurumun tüm çevresel çalışmalarına yön veren çevresel etki strateji ve politikalanıdır. Çevresel konuların yönetim yaklaşımı iki endekste de; enerji, su, emisyonlar, atık sular ve atıklar, biyoçeşitlilik, çevresel uyum, tedarikçilerin çevresel uyumu başlıklarında öncelikli alanları da dahil edilecek şekilde sorgulanmaktadır. İlgili politikaların tedarikçiler ve tedarik zinciri hizmetleri kapsamında yaygınlaştırılmasını da yine aynı şekilde çevresel etki politikaları altında sınıflandırmak mümkündür. GRI'dan farklı olarak THE Impact bu konularda yapılan ortaklık ve iş birliklerini ve kampüs içi uygulamaları sorgulamaktadır. Her iki endekste de yer alan iklim değişikliği konusuna, GRI daha çok risk ve finans odaklı yaklaşırken, THE Impact'in daha çok hükümet ortaklı çalışmalara kattlım çerçevesinde yaklaştı̆ı görülmektedir. THE Impact, GRI'dan farklı olarak; sürdürülebilir tarım politikası ve kampüsün yaya ulaşımına olanak vermesi, bisiklet yollanı vb. çalışmalar dahil sürdürülebilir ulaşım kapsamındaki çalışmaları sorgulamakta, üniversitenin bu noktada topluma olan katkısını öne çıkarmaktadır. GreenMetric ise çevre odaklı bir endeks olmakla birlikte, bu süreçleri strateji ve yönetim yaklaşımı altında değil uygulamalar kapsaminda ele almaktadır. 
Tablo 5. Yönetişim ve Strateji: Çevresel Etki Politikaları

\begin{tabular}{|c|c|}
\hline GRI & THE IMPACT \\
\hline Çevresel Etki Politikaları & Çevresel Etki Politikaları \\
\hline $\begin{array}{l}\text { Enerji verimliliğine yönelik politikalar ve } \\
\text { yönetim yaklaşımı (103-1, 103-2,103-3) }\end{array}$ & $\begin{array}{c}\text { Enerji verimliliği ve enerji tüketimini azaltmaya } \\
\text { yönelik politikalar ve planlar (SDG7-7.2., 7.2.1., } \\
\text { 7.2.2., 7.2.4., 7.2.6, 7.4., 7.4.2., 7.4.4.) }\end{array}$ \\
\hline- & $\begin{array}{l}\text { Enerij verimliliğini sağlamaya yönelik yapılan iş } \\
\text { birlikleri ve hükümeti destekleyici faaliyetler }\end{array}$ \\
\hline Atık su yönetim yaklaşımı $(103-1,103-2,103-3)$ & $\begin{array}{c}\text { Su ekosisteminin korunması ve sürdürülmesine } \\
\text { yönelik politikalar (SDG14-14.3.2., 14.4.2, 14.4.3., } \\
\text { 14.5., 14.5.1.)/Bu konuda yerel halk ile yapılan iş } \\
\text { birlikleri (SDG14-14.5.4.)/Su güvenliğiyle ilgili yerel, } \\
\text { bölgesel, ulusal ve uluslararası hükümetlerle } \\
\text { ortaklıklar (SDG6-6.5.5.) }\end{array}$ \\
\hline Atık yönetimi politikası $(103-1,103-2,103-3)$ & $\begin{array}{c}\text { Tehlikeli maddeleri de içine alacak şekilde atık } \\
\text { yönetimi politikası (SDG12-12.2.3., 12.2.4., 12.2.5., } \\
\text { 12.2.6.)/Bu politikaların tedarikçilere } \\
\text { yaygınlaştırlması politikaları (SDG12-12.2.7., } \\
\text { 12.2.8.)/Kampüste plastik atı̆̆1 azaltmaya yönelik } \\
\text { politikalar (SDG15-15.4.2.) }\end{array}$ \\
\hline $\begin{array}{l}\text { Biyoçeşitliliği korumaya yönelik politikalar } \\
\qquad(103-1,103-2,103-3)\end{array}$ & $\begin{array}{l}\text { Ekosistemi, biyoçeşitliliği ve risk altında olan türleri } \\
\text { korumaya yönelik politikalar (SDG15- 15.2.3., 15.3.1., } \\
\text { 15.3.2., 15.3.3., 15.3.4.)/Ekosistemi korumak için } \\
\text { yerel halkla yapılan iş birlikleri (SDG15- 15.3.5.) }\end{array}$ \\
\hline $\begin{array}{l}\text { Emisyonlar yönetim yaklaşımı (103-1, 103-2, } \\
103-3)\end{array}$ & $\begin{array}{l}\text { Yürüme, bisiklet, kamu ulaşımı, motorsiklet, scooter } \\
\text { gibi sürdürülebilir ulaşım kapsamında alınan önlem ve } \\
\text { belirlenen hedefler (SDG11-11.4.1.)/Daha iyi } \\
\text { sürdürülebilir ulaşımı desteklemek için politika ve } \\
\text { girişimler (SDG11-11.4.2., SDG15-15.4.3.)/Uzaktan } \\
\text { çalışma sistemleri (SDG11-11.4.3.)/Yaya yoluna } \\
\text { öncelik veren kampüs (SDG11-11.4.6.)/Karbon } \\
\text { nörtlüğü başarmak için taahhütler (SDG13-13.4.1.) }\end{array}$ \\
\hline $\begin{array}{l}\text { İklim değişikliğinin kurumun finansal başarısına } \\
\text { etkisi, risk ve firsatlar (201-2) }\end{array}$ & $\begin{array}{c}\text { İklim değişikliği etkileri ve risklerini yok etmeye } \\
\text { yönelik yapılan çalışmalar/İklim değişikliği planı ve } \\
\text { hükümetle yapılan ortaklıklar (SDG13-13.3.2., 13.3.3., } \\
13.3 .4,13.3 .5 .)\end{array}$ \\
\hline- & $\begin{array}{l}\text { Sürdürülebilir tarım politikaları ve konuyla ilgili } \\
\text { çalışmalar (SDG15-15.2.2.)/Etik yemek kaynağı ve } \\
\text { tedarikçi politikaları (SDG12-12.2.1.) }\end{array}$ \\
\hline
\end{tabular}

Çevresel etki politikaları kapsamında iki endeksin de tüm çevre konularını içine alacak sorgulamalar yaptığ1 görülmektedir. GRI, THE Impact'e göre bu konuda sürdürülebilir tarım ve ulaşım alanlarında göstergeleri olmaması açısından eksik kalmaktadır. Bununla birlikte çevresel farkındalık çalışmalarının da bir strateji olarak uygulanması önemli olduğundan, bu konudaki politikanın sorgulanmaması THE Impact'in eksik noktası olarak görülmektedir.

\section{Sonuç}

Sürdürülebilir üniversiteler günümüzün öne çıkan konularından biridir. Üniversiteler kapsamında yapılan sürdürülebilirlik çalışmalanı üniversitelerin eğitim-öğretim, araştırma faaliyetleri standartlannı artırmanın yanı sıra toplum için değer yaratan ve toplumun gelişimi ve kalkınması için üzerlerine düşen sorumluluğu daha etkin bir şekilde yerine getirmeleri için önem taşıyan uygulamaları içermektedir. Bu çalışmada; üniversite endekslerinden sürdürülebilirlik konusunu öne çıkaran Times Yüksek Öğrenim Etki Sıralaması (Times Higher Education World University Rankings - THE Impact); çevresel çalışmaların önemine vurgu yapan IU GreenMetric Dünya Üniversite Endeksi (IU GreenMetric World University Ranking) ve kurum ve kuruluşların genel sürdürülebilirlik çalışmalarını değerlendiren ve dünyada en çok 
kullanılan standart olan Küresel Raporlama Girişimi (Global Reporting Initiative - GRI) sürdürülebilirlik raporlaması standardı endekslerinin strateji ve yönetişim ve bu alandaki iletişim çalışmaları alanlarındaki göstergelerinin karşılaştırmalı analizi yapılmıştır. Yapılan analiz doğrultusunda sürdürülebilir üniversitelerin 'Yönetişim ve Strateji' ve bu alandaki iletişim çalışmalant 'Temel Strateji ve Politikalar/Yönetim Yapısı', 'Etik', 'Sosyal Alanlar: Cinsiyet Eşitliği - Eşitlik ve Çeşitlilik - İnsan Haklanı' ve 'Çevresel Etki Politikaları' ana başlıkları altında sınıflandırılmıştır.

Tablo 6. Temel Alanlar Kapsamında Ele Alınan Ana Konu Başlıkları

\begin{tabular}{|c|c|}
\hline $\begin{array}{l}\text { 'Yönetişim ve Strateji' } \\
\text { Altındaki Temel Alanlar }\end{array}$ & Alan Kapsamında Ele Alınan Ana Konu Başlıkları \\
\hline $\begin{array}{c}\text { Temel Strateji ve } \\
\text { Politikalar/Yönetim } \\
\text { Yapısı }\end{array}$ & $\begin{array}{l}\text { 'Sürdürülebilir üniversite kapsamında öncelikli konuların } \\
\text { açıklanması'; 'Paydaşların tanımlanması ve paydaş katılım } \\
\text { stratejilerinin belirlenmesi'; 'Yerel paydaşların katılımının } \\
\text { sağlanması'; 'Kurumun yaptığı iş birlikleri'; 'STK iş } \\
\text { birlikleri'; 'Öğrenci temsiliyeti'; 'SDG'lere katkı'; } \\
\text { 'Sürdürülebilirlik raporlaması'. }\end{array}$ \\
\hline Etik & $\begin{array}{l}\text { 'Yolsuzluğa yönelik alınan önlemler'; 'Standart ve } \\
\text { prosedürler'; 'Etik eğitimleri'. }\end{array}$ \\
\hline Cinsiyet Eşitliği & $\begin{array}{l}\text { 'Üniversitedeki kadın öğrenci sayısının artırılması'; 'Idari ve } \\
\text { akademik kadrolardaki kadın istihdamının artıılması'; } \\
\text { 'Anne-bebek politikalarının varlığı'; 'Kadın-erkek } \\
\text { çalışanların maaşları arasındaki eşitlik'. }\end{array}$ \\
\hline Eşitlik ve Çeşitlilik & $\begin{array}{c}\text { 'Her türlü ayrımcılığın yok edilmesine yönelik yönetim } \\
\text { yaklaşımlarının varlığı'; 'Eşitlik ve çeşitlilik alanında çalışan } \\
\text { komitelerin varlığı'. }\end{array}$ \\
\hline İnsan Haklar1 & $\begin{array}{l}\text { 'Çocuk ve zorla işçi politikaları’; ‘Tedarikçilerin çalışanlarına } \\
\text { eşit haklar sağlandığının kontrol edilmesine yönelik } \\
\text { politikalar'; 'Akademik özgürlügüu sağlamaya yönelik } \\
\text { politikalar'; 'Üniversitenin işçi hakları, toplu iş sözleşmesi } \\
\text { vb. sözleşmeleri destekleyen birlikleri tanıması'. }\end{array}$ \\
\hline Çevresel Etki Politikaları & $\begin{array}{c}\text { 'Enerji'; 'Su'; 'Emisyonlar'; 'Atık sular ve atıklar'; } \\
\text { 'Biyoçeşitlilik'; 'Çevresel uyum'; 'Tedarikçilerin çevresel } \\
\text { uyumu'; 'Çevresel farkındalık çalıșmaları'. }\end{array}$ \\
\hline
\end{tabular}

$\mathrm{Bu}$ ana başlıklar altında sürdürülebilir bir üniversitenin yönetişim, strateji ve iletişim temel çalışmaları arasında önceliklendirilmesi gereken göstergeler şu şekilde ortaya çıkmıştır: 'Temel Strateji ve Politikalar/Yönetim Yapısı' alanında sürdürülebilir üniversite kapsamında öncelikli konulanın açıklanması, paydaşların tanımlanması ve paydaş katılım stratejilerinin belirlenmesi, yerel paydaşların katılımının sağlanması, kurumun yaptığ iş birlikleri, STK iş birlikleri, öğrenci temsiliyeti, SDG'lere katk1 ve son olarak sürdürülebilirlik raporlaması öne çıkan konular arasında yer almaktadır. 'Etik' başlığında ise, yolsuzluğa yönelik alınan önlemler, standart ve prosedürler ile etik konulu eğitimlerin verilmesi önemli göstergeler arasındadır. 'Cinsiyet Eşitliği' kapsamındaki temel yönetim yaklaşımlanın yanı sıra; üniversitedeki kadın öğrenci sayısının artırılması, idari ve akademik kadrolardaki kadın istihdamının artırılması, anne-bebek politikalarının varlığı, kadın-erkek çalışanların maaşları arasındaki eşitlik konuları sürdürülebilir üniversiteler için önemli göstergeler olarak ortaya çıkmıştır. 'Eşitlik ve Çeşitlilik' kapsamında ise, her türlü ayrımcılığın yok edilmesine yönelik yönetim yaklaşımlarının varlığının yanı sıra, bu alanda çalışan komitelerin varlı̆̆1 önem kazanmaktadır. 'Insan Hakları' başlığ1 altında ise, çocuk ve zorla işçi politikaları, tedarikçilerin çalışanlarına eşit haklar sağlandığının kontrol edilmesine yönelik politikalar, akademik özgürlüğü sağlamaya yönelik politikalar, üniversitenin işçi haklanı, toplu iş sözleşmesi vb. sözleşmeleri destekleyen birlikleri tanıması ve üyelikleri öne çıkan göstergeleri oluşturmaktadır. 'Çevresel Etki Politikaları' kapsamında; enerji, su, emisyonlar, atık sular ve atıklar, biyoçeşitlilik, çevresel uyum, tedarikçilerin çevresel uyumu, çevresel farkındalık çalışmaları başlıkları öncelikli alanları temsil etmektedir. Bunlara ek olarak kampüs içindeki yaya ve bisiklet alanları ile iklim değişikliğine yönelik olarak uygulanan sürdürülebilir tarım politikaları diğer önemli göstergeleri oluşturmaktadır. 
Her bir ana başlık özelinde endekslerin yapılan karşılaştırmalı analizinde; Temel Strateji ve Politikalar/Yönetim Yapısı kapsamında bakıldığında sürdürülebilirlik raporlaması yapılıp yapılmadığını her üç endeksin de sorguladığ1 ve bu noktada birbirini tamamladığ1 görülmektedir. Aynı şekilde paydaş katılımı çalışmaları GRI ve THE Impact tarafından detaylı olarak sorgulanması açısından önemlidir. Konunun üniversite organlarını içerecek şekilde THE Impact endeksinde detaylı olarak sorgulanması sürdürülebilir üniversite kriterleri açısından değerlidir. Bununla birlikte, THE Impact, tüm SDG'leri içeren bir endeks olmasına rağmen, üniversite içindeki yönetişim ve sürdürülebilir yönetim yapısını, GRI'ın yaptı̆̆1 şekilde detaylı olarak sorgulamamaktadır. Sürdürülebilirlik çalışmalarının koordineli bir şekilde yürütülebilmesi için öncelikle üst yönetimin bu çalışmaların itici gücü olarak liderlik etmesi ve önceliklerini belirlemesi en önemli noktayı oluşturmaktadır. Ancak THE Impact endeksinin yönetim yapısı ile risk ve firsatlar ile sürdürülebilirlik strateji ve politikalarının belirlenmesinde önemli olan öncelikli konuları sorgulamaması, THE Impact'in iki önemli eksiği olarak ortaya çıkmaktadır. Endeks, bunun yerine 17 SDG maddesi altında sınıflandırdığı göstergeler çerçevesinde üniversitelerin strateji ve politikalarını sorgulamaktadır. GRI ise her konudaki stratejiyi genel çerçevede sorgulaması, üniversite özeline indirebilecek noktalar1 içermemesi açısından eksik kalmaktadır. Bu nedenle üniversite sürdürülebilirlik çalışmalarında sadece bu standardın kullanılması, bazı konulanın atlanmasına neden olabilir. GreenMetric ise bu çerçevede sadece öğrenci kulüplerini ve raporlama göstergelerini almış, diğer noktalarda herhangi bir sorgulama yapmamıştur. GreenMetrick her ne kadar çevresel endeks olarak ortaya çıksa da, 'Temel Strateji ve Politikalar/Yönetim Yapısı' ana başlığı altındaki konular, bu alanı da kapsadığından diğer iki endeksin sorguladığı noktaların bu endekste sorgulanmaması bir eksiklik olarak ortaya çıkmaktadır.

'Etik' ana başlığı altında, GRI konuyu kurumların tüm iş yapış süreçlerindeki etiğe yönelik alınan önlemler, mekanizmalar ve uygulamalar, eğitimler olarak kapsamlı bir şekilde ele almaktadır. Etik süreçler, bir kurumun sürdürülebilirliğinin temel faktörlerinin başında gelmektedir. Üniversitelerin bu konunun dışında kalması beklenemez. Özellikle özel üniversitelerin sayısının artmasıyla birlikte sürdürülebilirlik alanında etik konusu özellikle ön plana çıkacaktır. Bu nedenle, THE Impact endeksinin konuya çok fazla vurgu yapmaması ve süreçleri etik kapsamında değerlendirmemesi endeksin eksikliği olarak ortaya çıkmaktadır.

Sosyal Alanlar kapsamında; 'Cinsiyet Eşitliği - Eşitlik ve Çeşitlilik - İnsan Hakları' ana başlikları her iki endekste de oldukça detaylı bir çerçevede ele alınmaktadır. Cinsiyet eşitliği kapsamında her iki endeks de fırsat ve cinsiyet eşitliğini sağlamaya ve kadına karşı ayrımcılı̆̆1 önlemeye yönelik politikaları sorgulamaktadır. Bu çerçevede kadın istihdamını artırmaya, kadın yönetici sayısını yükseltmeye, kadınerkek maaş dengesini sağlamaya yönelik stratejiler, anne-bebek politikası kapsamında yapılan çalışmalar ele alınmaktadır. THE Impact GRI'dan farklı olarak bu konuda, sürdürülebilir üniversitelerin bu alandaki önemli bir performansı olarak ele alınabilecek üniversiteye yapılan kadın öğrenci başvuru ve mezun sayılarını göstergeleri arasına almıştır. Bu noktanın endeksin güçlü yönü olduğu ileri sürülebilir. Diğer yönden THE Impact, GRI endeksinin sorduğu gibi üniversite içi çalışan kadın çalışan sayısı, kadınların terfi oranlarını sorgulamayarak kurum içi cinsiyet eşitliği alanında eksiklik göstermektedir. Eşitlik ve Çeşitlilik başlığı altında her iki endeks de ayrımcıllğı önlemeye ve çeşitliliği sağlamaya yönelik politikaları sorgulamakla birlikte, GRI konuyu daha genel çerçevede ele almakta, alt başlıkları doldurma kısmını kurumun kendisine bırakmaktadır. THE Impact ise bu konuya özellikle vurgu yapmakta, eşitlik ve çeşitlilik komiteleri dahil olmak üzere, taciz karşıtı politikalar, eğitim ve istihdam dezavantajı yaratan ayrımcıllŭı engellemeye yönelik politikalar gibi hem üniversite özelinde hem de toplumda önemli yer teşkil eden göstergeleri endeks göstergeleri arasına almıştır. Yine pozitif ayrımcılık politikalarını sorgulayarak hem cinsiyet eşitliğine hem de çeşitlilik stratejilerine hizmet edecek yaklaşımları sorgulamıştır. Bu noktada THE Impact'in konunun tüm yönlerini ele aldı̆̆1 ileri sürülebilir. İnsan Hakları başlı̆̆ında ise iki endeksin de toplu iş sözleşmesi, çocuk ve zorla işçi çalıştırma, tedarikçilerin sosyal değerlendirmesi ile çalışanlannna eşit haklar sağlanmasına yönelik politikalar kapsamında göstergeleri bulunmaktadır ve bu açıdan birbiriyle bire bir örtüşmektedir. Bu başlıkta GRI ayı zamanda yerel halkın haklarına yönelik yönetim yaklaşımını ve alanda imzalanan anlaşmaları da sorgulamaktadır. THE Impact ise bu alanda üniversiteler için son derece önemli olan akademik özgürlüğü destekleme politikasına vurgu yapmaktadır. Endekslerin bu alanda verilen eğitimleri sorgulamamaları ise iki endeksin de eksikliği olarak ortaya çıkmaktadır. 
Çevresel etki politikaları, iki endekste de; enerji, su, emisyonlar, atık sular ve atıklar, biyoçeşitlilik, çevresel uyum, tedarikçilerin çevresel uyumu başlıklarında öncelikli alanları da dahil edilecek şekilde sorgulanmaktadır. Bu noktada iki endeksin de birbiriyle örtüş̧ügü görülmektedir. THE Impact ayrıca bu konuda başta hükümetle yapılanlar olmak üzere diğer işbirlikleri ve ortaklıklanı da sorgulaması açısından daha dayanaklı bir sorgulama yapmaktadır. GRI, THE Impact endeksine göre bu alanda sürdürülebilir tarım ve ulaşım alanlarında göstergeleri içermemesi açısından eksik kalmaktadır. Bununla birlikte çevresel farkındalık çalışmalarının da bir strateji olarak uygulanması önemli olduğundan, bu konudaki politikanın sorgulanmaması THE Impact'in eksik noktası olarak görülmektedir. GreenMetric ise çevresel bir endeks olmasına rağmen, çevreyle ilgili tüm çalışmalara değinmekle birlikte yönetişim ve strateji alanında tepe sorgulamalan yapmaması açısından eksiklik göstermektedir.

Gerçekleştirilen karşılaştırmalı analizde; üç endeksin ele aldığı en önemli gösterge sürdürülebilirlik raporlamasıdır. Ortaya çıkarılan; 'Temel Strateji ve Politikalar/Yönetim Yapısı', 'Etik', 'Cinsiyet Eşitliği Eşitlik ve Çeşitlilik - Insan Hakları', 'Çevresel Etki Politikaları' alanlarının tümünde endekslerin ortak göstergeleri bulunmasına rağmen, üniversitelerin yapıları göz önünde bulundurulduğunda, her birinin eksik kaldığ1 bazı temel noktaların olduğu görülmüştür. Bu kapsamda, üniversitelerde sürdürülebilirlik uygulamalarının ne şekilde olması gerektiğine rehberlik yapması amacıyla; her bir endeksin eksik kaldığ1 göstergeleri içerecek şekilde yeni bir yol haritasının belirlenmesi faydalı olacaktır.

Üniversitelerin sürdürülebilirlik çalışmalarındaki verimin en önemli noktasını ise iletişim çalışmaları oluşturmaktadır. Üniversiteler bu sayede sürdürülebilirlik strateji ve politikalarını daha bilinir kılarak, yaklaşımların bu doğrultuda şekillenmesini sağlamaktadırlar. Tüm bu strateji ve politikaların gerek üniversite içinde uygulanabilmesi, gerek toplumda farkındalığın yaratılması, gerekse diğer üniversite ve kurumlara örnek teşkil etmesi için stratejik iletişiminin yapılması büyük önem taşımaktadır. Sürdürülebilir üniversite kavramının ve uygulamalarının yerleşebilmesi ve topluma yaygınlaşabilmesi için üniversitelerin hem iç hem de dış paydaşlarına, hem yönetim yaklaşımlarını bildirmeleri hem de yaptıklanı çalışmaların sürekli iletişimini yapmaları, çalışmalarının içine paydaşlarını da dahil etmeleri gerekmektedir. Bu sayede yarattıkları katma değeri daha da artırmaları mümkün olacaktır.

\section{Extended Abstract}

\section{Purpose}

In the recent years, the institutions' responsibilities regarding the environment and society, towards all their stakeholders, have been becoming more and more important. The concept of sustainability that emerged as a result of this approach has gained importance for universities as well. Sustainability ranking systems have started to be developed for universities in order to be a guide in this area. This study aims to determine the basic indicators that a sustainable university should prioritize within the framework of governance, strategy and communication. In this context; It is aimed to reveal the scope in which the strategy and governance studies of a sustainable university should be structured by making a comparative analysis of 3 main indexes that highlight the issue of sustainability, and to examine the tools required for sustainability communication.

\section{Methodology}

In this research, the 3 most frequently used main indexes in the field of sustainability were determined as follows; Times Higher Education World University Rankings (THE Impact), which highlights sustainability in university indexes; The IU GreenMetric World University Index, which emphasizes the importance of environmental studies, and the Global Reporting Initiative (GRI) sustainability reporting standard indexes, which evaluates the general sustainability studies of institutions and organizations and which is the most widely used standard in the World. All indicators of the indexes were examined, and indicators for the areas of strategy and governance were obtained and comparative analysis of these determined indicators was realized. In addition, examples of tools required for sustainability communication were also discussed. In this framework, an approach proposal has been presented regarding the basic indicators that a sustainable university should prioritize within the framework of governance, strategy and communication. 


\section{Findings}

In the study, THE Impact, GRI and GreenMetric sustainability indexes were examined in detail in terms of governance and strategy. The study is important in terms of contributing to the literature, since a comparative analysis of universities in terms of sustainable governance and strategy has not been conducted so far.

Considering the contents of three different indexes analyzed within the scope of the research, it has been revealed that; the studies of under the name of universities' sustainability governance and strategy can be classified under the main titles of: "Main Strategies and Policies / Management Structure", "Ethics", "Social Aspects: Gender Equality - Equality and Diversity - Human Rights", "Environmental Impact Policies".

Under these main headings, the indicators that should be prioritized among the basic studies of governance, strategy and communication by the sustainable universities have emerged as follows: Explaining the priority issues within the scope of the sustainable university, defining the stakeholders, determining the stakeholder participation strategies, making collaborations with the institutions and NGOs, student representation in the committees, contribution to SDGs and lastly, sustainability reporting are among the main issues in the field of 'Basic Strategy and Policies/Management Structure'. The measures taken against corruption, regarding standards and procedures and providing ethical trainings are among the important indicators under the title of 'ethics'.

Besides the basic management approaches within the scope of 'Gender Equality'; Increasing the number of female students in the university, increasing female staff both in administrative and academic area, existence of mother-infant policies, and equality between female and male employees' salaries have emerged as important indicators for sustainable universities. Within the scope of "Equality and Diversity", apart from the the existence of management approaches to eliminate all kinds of discrimination, existence of committees working in this field is important. Child and forced labor policies, policies for controlling the suppliers' human rights applications, policies to ensure academic freedom, labor agreement freedom, membership of unions supporting human rights are the main indicators under the title of "Human Rights".

"Environmental Impact Policies" represent priority areas under the topics of energy, water, emissions, waste water and waste, biodiversity, environmental compliance, environmental compliance of suppliers and environmental awareness. In addition to these, the pedestrian and bicycle areas in the campus and the sustainable agricultural policies implemented for fighting against climate change are among the other important indicators.

\section{Conclusion and Discussion}

In the comparative analysis carried out; it is found out that, the most important indicator addressed by three indexes is sustainability reporting. Although there are common indicators in the fields of 'Main Strategies and Policies / Management Structure', 'Ethics', 'Social Aspects: Gender Equality - Equality and Diversity - Human Rights', 'Environmental Impact Policies', considering the structures of universities, it has been seen that there are some missing points in each indexes. In this context, in order to guide how the sustainability practices should be at universities; It will be useful to determine a new roadmap that includes the indicators that each index is missing.

Communication studies is one of the most important point of sustainability studies of universities. In this way, universities make their sustainability strategies and policies more known. Communication is of great importance in order to implement all these strategies and policies within the university, to create awareness in the society, and to be a role model for other universities and institutions. Universities should not only inform their internal and external stakeholders about their management approach, but also continuously communicate with their stakeholders and inform them about their approaches and sustainability practices. In this way, it will be possible for the universities to increase the added value they create. 


\section{Kaynakça}

Alshuwaikhat, HM., Abubakar, IR., Aina, YA. \& Saghir, B. (2017). Networking The Sustainable Campus Awards: Engaging with The Higher Education Institutions in Developing Countries. İcinde Walter Leal Filho, Constantina Skanavis, Arminda do Paco, Judy Rogers, Olga Kuznetsova, Paula Castro (Ed.), Handbook of Theory and Practice of Sustainable Development in Higher Education. Switzerland: Springer.

GreenMetric (2020). UI Greenmetric | World University Rankings, http://greenmetric.ui.ac.id/. [Erişim Tarihi: 29 Ağustos 2020].

GRI (Global Reporting Initiative). (2020a). About GRI, https://www.globalreporting.org/Information/about-gri/Pages/default.aspx. [Erişim Tarihi: 23 Haziran 2020].

GRI (Global Reporting Initiative). (2020b). GRI Sustainability Disclosure Database, https://database.globalreporting.org/search/. [Erişim Tarihi: 01 Eylül 2020].

Hohnen, P. (2012). The Future of Sustainability Reporting. Chatham House. EEDP Programme Paper:

2012/02,https://www.chathamhouse.org/sites/default/files/public/Research/Energy,\%20Environment \%20and\%20Development/0112pp_hohnen.pdf. [Erişim Tarihi: 24 Haziran 2020].

IFC. (2010). Getting More Value Out of Sustainability Reporting. Connecting IFC's Sustainability Performance Standards and The RRI Reporting Framework, https://www.ifc.org/wps/wcm/connect/8b163f49-d694-4879-aec0-

9dbd10059eb0/WB_IFC_GettingMoreValue.pdf?MOD=AJPERES\&CACHEID=ROOTWORKSPACE -8b163f49-d694-4879-aec0-9dbd10059eb0-jkD0-WU. [Erişim Tarihi: 23 Haziran 2020].

Lauder, A., Sari, R. F., Suwartha, N., Tjahjono, G. (2015). Critical Review of a Global Campus Sustainability Ranking: GreenMetric. Journal of Cleaner Production, 108, 852-863.

Levi-Faur, D. (2012). From Big Government To Big Governance. UK: The Oxford Handbook of Governance.

Lozano, R., Ceulemans, K., Alonso-Almeida, M., Huisingh, D., Lozano, F. J., Waas, T., Lambrechts, W., Lukman, R., \& Hugé, J. (2015). A Review of Commitment and Implementation of Sustainable Development in Higher Education: Results from a Worldwide Survey. Journal of Cleaner Production, 108, 1-18.

Marginson, S. \& Van der Wende, M. (2007). To Rank or To Be Ranked: The Impact of Global Rankings in Higher Education. Journal of Studies in Intarnational Education, 11(3-4):306-329.

Nickols, F. (2008). Strategy, Strategic Management, Strategic Planning and Strategic Thinking. Distance Consulting https://www.researchgate.net/publication/242698739_STRATEGY_STRATEGIC_MANAGEMENT_ STRATEGIC_PLANNING_AND_STRATEGIC_THINKING. [Erişim Tarihi: 29 Ağustos 2020].

OECD. (2008). Gender and Sustainable Development: Maximising The Economic, Social And Environmental Role of Women, https://www.oecd.org/social/40881538.pdf. [Erişim Tarihi: 01 Eylül 2020].

Ragazzi, M. \& Ghidini, F. (2017). Environmental Sustainability of Universities: Critical Analysis of a Green Ranking. Energy Procedia, 119, 111-120.

Rioplus. (2006). Strategic Communication for Sustainable Development A Conceptual Overview. Environmental Policy and Promotion of Strategies for Sustainable Development. Deutsche Gesellschaft für Technische Zusammenarbeit (GTZ) GmbH (Ed.). Germany. https://www.cbd.int/cepa/toolkit/2008/doc/Strategic $\% 20$ Communication $\% 20$ for $\% 20$ Sustainable $\% 20$ de velopment.pdf. [Erişim Tarihi: 24 Ağustos 2020].

Suwartha, N. \& Sari, R.F. (2013). Evaluating UI GreenMetric As a Tool to Support Green Universities Development: Assessment of the Year 2011 Ranking. Journal of Cleaner Production, 61:46-53.

Thakur, M. (2007). The Impact of Ranking Systems on Higher Education and Its Stakeholders. Journal of Institutional Research, 13(1):83-96, https://peopleandplanet.org/university-league. [Erişim Tarihi: 02 Eylül 2020]. 
THE (Times Higher Education). (2020). Impact Ranking, https://www.timeshighereducation.com/rankings/impact/2020/overall\#!/page/0/length/25/sort_by/ra $\mathrm{nk} /$ sort_order/asc/cols/undefined. [Erişim Tarihi: 26 Ekim 2020].

UN. (2016). Chief Executives Board for Coordination. CEB/2016/6/Add.1. https://www.unsceb.org/CEBPublicFiles/CEB_2016_6\%20_Add.1\%20\%28inequalities\%20framework \%29.pdf. [Erişim Tarihi: 28 Ağustos 2020].

UNGC. (2020). Social Sustainability. https://www.unglobalcompact.org/what-is-gc/our-work/social. [Erişim Tarihi: 12 Ağustos 2020].

WCED. (1987). Our Common Future. Oxford: Oxford University Press.

Ysa, T., Albareda, A., Colom, J., Ramon, A. Carrion, M. \& Segura, L. (2014). Governance of Addictions: European Public Policies. UK: Oxford Press.

Zimmerli, W., Richter, K. \& Holzinger, M. (2007). Corporate Ethics and Corporate Governance. NYC: Springer. 